\title{
ATG13 Gene
}

National Cancer Institute

\section{Source}

National Cancer Institute. AT G13 Gene. NCI Thesaurus. Code C126135.

This gene plays a role in both autophagosome formation and mitophagy. 